University of Windsor

Scholarship at UWindsor

1985

\title{
Enzymes of the intermediary carbohydrate metabolism of Polyangium cellulosum.
}

\author{
Renu. Sarao \\ University of Windsor
}

Follow this and additional works at: https://scholar.uwindsor.ca/etd

\section{Recommended Citation}

Sarao, Renu., "Enzymes of the intermediary carbohydrate metabolism of Polyangium cellulosum." (1985). Electronic Theses and Dissertations. 1946.

https://scholar.uwindsor.ca/etd/1946

This online database contains the full-text of PhD dissertations and Masters' theses of University of Windsor students from 1954 forward. These documents are made available for personal study and research purposes only, in accordance with the Canadian Copyright Act and the Creative Commons license-CC BY-NC-ND (Attribution, Non-Commercial, No Derivative Works). Under this license, works must always be attributed to the copyright holder (original author), cannot be used for any commercial purposes, and may not be altered. Any other use would require the permission of the copyright holder. Students may inquire about withdrawing their dissertation and/or thesis from this database. For additional inquiries, please contact the repository administrator via email (scholarship@uwindsor.ca) or by telephone at 519-253-3000ext. 3208. 


\section{CANADIAN THESES ON MICROFICHE}

\section{THĖSES CANADIENNES SUR MICROFICHE}

National Library of Canada

Collections Development Branch

Canadian Theses on Microfiche Service

Ottawa. Canada

KIA ON4

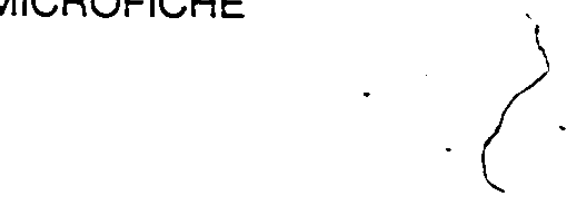

Bibliotheque nationale du Canada

Direction du développement des coilections

Service des theses canadiennes sur microfiche

-

\section{NOTICE}

The quality of this microfiche is heavily dependent upon the quality of the original thesis submitted for microfilming. Every effort has been made to ensure the highest quality of reproduction possible.

If pages are missing. contact the university which granted the degree.

Some pages may have indistinct print especially if the original pages were typed with a poor typewriter ribbon or if the university sent us an inferior photocopy.

Previously copyrighted materials (journal articles, published tests, etc.) are not filmed.

Reproduction in full or in part of this film is governed by the Canadian Copyright Act, R.S.C. 1970, c. C-30. Please read the authorization forms which accompany this thesis. $\cdot$

AVIS

La qualité de cette microfiche dépend grandement de la quainté de la these soumise au microfilmage. Nous avons tout fait pour assurer une qualité supérieure de reproduction.

S'il manque des pages, veuillez communiquer avec funiversité qui a conféré lé grade.

La qualité d'impression de certaines pages peut laisser à désirer, surtout si les pages originales ont été dactyographiées a l'aide d'un ruban use ou si l'université nous a fait parvenir une photocopie de qualité inférieure.

Les documents qui font dejà l'objet d'un droit d'auteur (articles de revue, examens publiés, etch dine sont pas microfilmés.

La reproduction, meme partielle, de ce microfilm est soumise à la Loi canadienne sur le droit d'auteur. SRC 1970, c. C-30. Veuillez prendre connaissance des formules d'autorisation qui accompagnent cette these.

\author{
THIS DISSERTATION \\ HAS BEEN MICROFILMED \\ EXACTLY AS RECEIVED.
}

\section{LA THĖSE A ÉTE் MICROFILMÉE TELLE QUE NOUS L'AVONS REÇUE}




\title{
Enzymes of The Intermediary Carbohydrate Metzbolism of Polyasgium cellulosum
}

\section{By}

\section{Renu Sarao.}

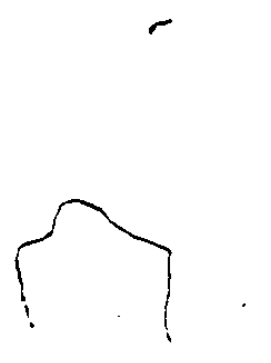

\author{
A Thesis \\ submitted to the Faculty of Graduate Studies \\ through the Department of \\ Biology in Partial Fulfillment of \\ the requirements for the Degree \\ of Master of Science at \\ The University of Windsor.
}

\author{
Windsor, Ontario, Canada \\ 1985
}



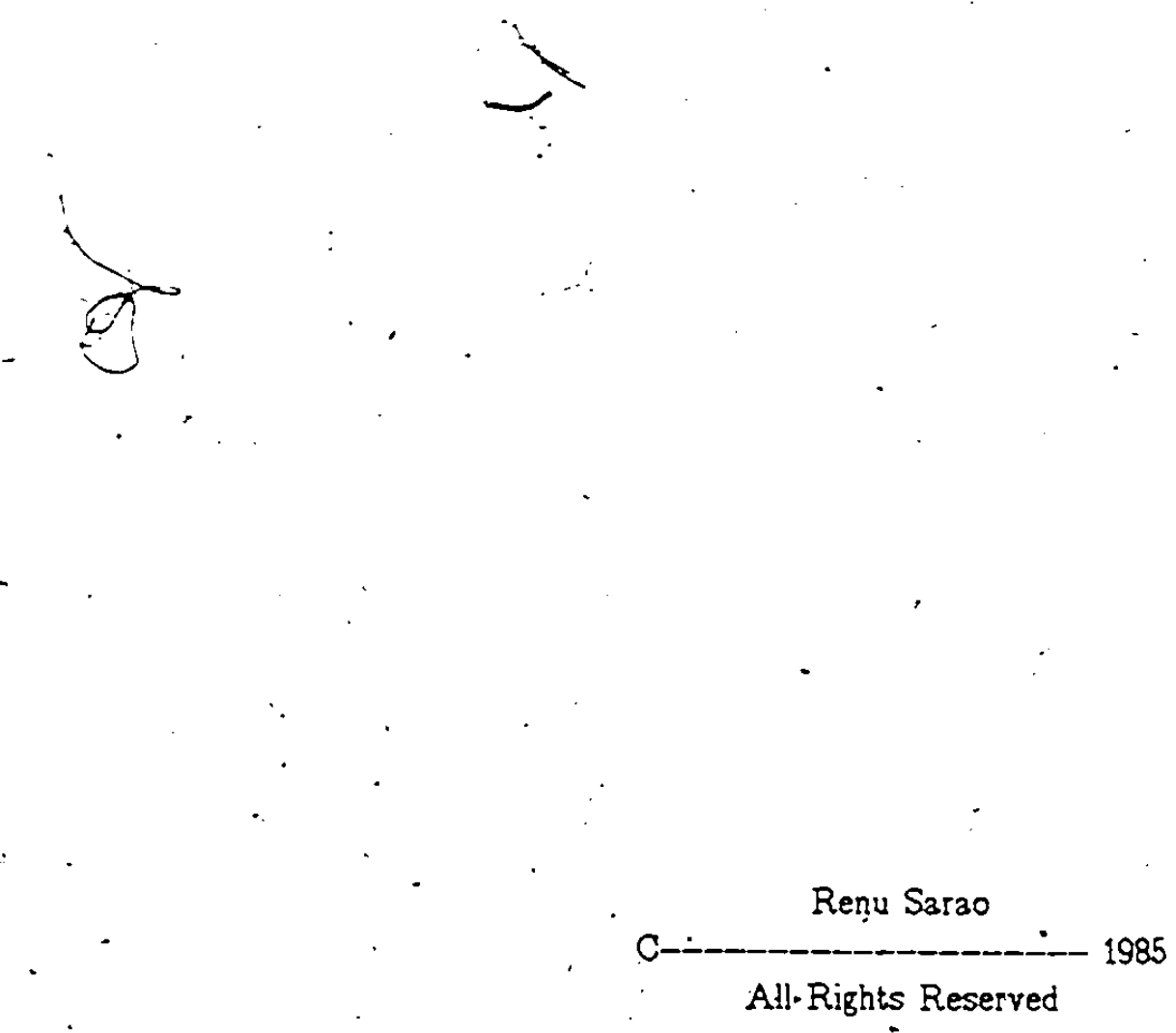

6

3

ii

819846 


\section{ABSTRACT}

Crude extracts of regetative cells of the cellulolytic myxobacter Polyongirm cellulosum contained significant levels of the enzymes of the tricarboxylic acid cycle and the glyoxylate cycle. Key enzymes of glycolysis and the pentose phosphate shunt were also detected. Specific activities of hexokinase and fructose-1,6-diphosphate aldolase exhibited a tenfold increase when the cells were grown in complex medium containing glucose.

Cytochromes of $a, b$ and $c$ type were demonstrated.

By the use of a dispersly growing strain of $P$. cellulossm, its generation time was determined to be 22-24 hours on SP.

This study suggests that the organism probably uses glycolysis and citric acid cycle for complete oxidation of glucose. The exact role of the glyoxylate cycle and pentose phosphate shunt cannot be deduced from this study.

This is the first report on the study of intermediary carbohydrate metabolism in any member of the family Polyangiaceas. 


\section{ACKNOWLEDGEMENTS}

I would like to express my appreciation to my friends, co-workers and the faculty and staff of the Department of Biology, for their support and friendship during the.course of $\mathrm{my}$ graduate studies here.

Special thanks are due to the members of my committee, Dr. N. Taylor and Dr. D. A. Cotter, and my advisor, Dr. H. D. MeCurdy Ir., for their guidance and advice which made this research possible.

Last but not the least, heartfelt thanks go out to $\mathrm{Mr}$ L. Passador and Ms. Martha Glares for their patience and help in explaining the basies of typing and the intricate working of a computer.

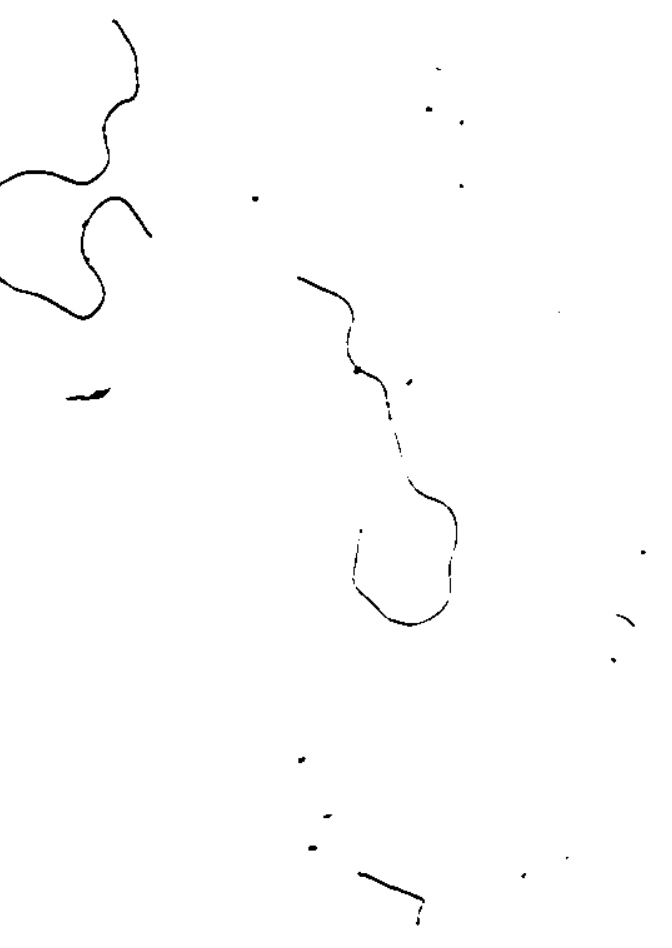




\section{TABLE OF CONTENTS}

\section{Page}

Abstract

Acknowledgements

List of Tables

Abbreviations

Introduction

Materials and Methods

Results

Discussion

Bibliography

Vita Auctoris vii

viii

1

iv

v

6

12

19

24

28 


\section{$\because$ \\ LIST OF TABLES}

Tables

1. Glycolytic activities in crude extracts of Polyergirm cellelosum.

2. Pentose phosphate activities in crude extracts of Polyangium cellslosum yegetative cells.

3. Specific activities of the TCA cycle enzymes in crude extracts of Polyangium cellulosum vegetative cells.

4. Glyoxylate shunt activities in cell free extracts of Polyongrum cellulosum.

5. Position of maxima in Absorption Spectra of sonicated Polyargsum cellulosem cells. 


\section{ABBREVIATIONS}

ADP - adenosine 5'-diphosphate

- APAD - 3-acetyl pyridine adenine dinucleotide

ATP - adenosine 5'-triphosphate

BSA - bovine serum albumin

COA - coenzyme A

$\mathrm{COA}-\mathrm{SH}$ - reduced coenzyme $\mathrm{A}$

DCIP - 2,6-dichlorophenolindophenol

NAD - nicotinamide adenine dinucleotide

NADH - reduced nicotinamide adenine dinucleotide

NADP - nicotinamide adenine dinucleotide phosphate

TCA - Tricarboxylic acid

Tris-HCL - Tris (hydroxymethyl) amino methane hydrochloride

TPP - thiamine pyrophosphate

1

i 
Polycrysiom cellulosum is a cellulolytic bacterium belonging to the family. Polyangiaceae (order Myxobacterales) (McCurdy, 1974). The regetative cells are cylindrical rods with blunt rounded ends. As in other myxobacterla, depletion of nutrients leads to aggregation of yegetative cells which then convert to myxospores. During this process of morphogenesis, the slender rods shorten and fatten and become physiologically dormant myxospores. The myxospores resemble the vegetative cells, are enclosed in sessile sporangia, and are neither refractile nor phase dense (McCurdy, 1974). The swarming colonies etch or erode the agar and may be pigmented yellow, red or orange. Dispersed growth can be achieved in liquid medium by frequent transferring (Reichenbach and Dworkin, 1980).

An understanding of the nutritional requirements of an organism provide insight into its ecological role as well as metabolism. There also appears to be a relationship between the nutritional milieu of a microbe and its morphological development (Dworkin, 1962). The fruiting body formation by Mysococcus (Oetker, 1953) and Chondromyces (Kuhlwein, 1950) has been shown to depend upon the nature of the medium.

Myxobacteria can be divided into two physiological groups. the bacteriolytic group and the cellulolytic group. Bacteriolytic myxobacteria feed cooperatively on other bacteria or yeast by secreting into the common milieu, hydrolytic enzymes that degrade other cells and their macromolecules, and then share the pooled products of digestion (Dworkin, 1972). The minimal nutritional requirements of the bacteriolytic myxobacters are still poorly 
understood. When grown on a chemically defined medium, the few strains studied so far require complex amino acid mixtures and relatively high concentrations of $\mathrm{Mg}^{2+}$ or $\mathrm{C}_{2}^{2+}$ for growth (Dworkin, 1962; Hemphill and Zahler, 1968; McCurdy and Khouw, 1969). Growth is much more efficient on complex media containing enzyme hydrolyzed casein (casitone). Loebeck and Klein (1956) and Dworkin (1962) suggested that peptides might be more efficiently utilized than amino acids.

Unlike these, the cellulolytic myxobacteria examined so far have simple nutritional requirements. They can grow in a defined medium containing an inorganic base supplemented with a single carbohydrate (Krzemieniewska and Krzemieniewski, 1937; Coucke, 1969). Cellulose will function as the sole carbon and energy source for Polyongium cellulosum It metabolizes insoluble crystalline cellulose as.well as soluble cellulose by producing both cell bound and extracellular cellulase and cellobiase activities (Godsey, 1976). In the laboratory the organism can use various carbohydrates as carbon sources. Growth takes place on xylose, maltose, dextrin, glucose, starch, cellobiose, arabinose and fructose (Krzemieniewska and Krzemieniewski, 1937). Potassium nitrate can be used as the sole source of nitrogen (Coucke, 1969). It can also use ammonia, urea, protein hydrolyzate and a few amino acids as nitrogen sources. Fruiting body formation occurs on media in which the carbohydrates are almost exhausted (Coucke, 1969). The best growth is obtained on Staniers medium containing $0.25 \%$ cellobiose (Peterson, 1969). Various concentrations of simpler carbon sources such as glucose and xylose, used in lieu of cellobiose, yield markedly inferior growth. Some isolates are glucose sensitive, and glucose is clearly toxic in concentrations higher than that used for cellobiose (Peterson, 1969). 
Detailed knowledge of the nutrition and metabolism of myxobacteria is restricted to Nysococcus scrthus. The conclusions derived from these studies probably apply, at least in part, to other bacteriolytic species, but the difference in nutrition of $P$. cellulosum suggests that the same may not apply to this cellulose decomposing organism: The pathway of glucose metabolism in this organism is unknown (Parish, 1979).

Studies on the intermediary metabolism of $M$ : santhus have indicated the absence of hexokinase and pyruvate kinase in both regetative cells and microcysts. All other glycolytic activities are present (Watson and Dworkin, 1968). The inability of this organism to metabolize sugars, and its -natritional dependence on amino acids as the source of arbon and energy suggest that the principal function of the Embden-Meyerhof enzymes is in gluconeogenesis. This is corroborated by the absence of pyruyate kinase as it catalyzes an essentially irreyersible glycolytic reaction and has no role in gluconeogenesis. Amino acidjs are sources of carbon and energy for $M$. sarthus, as are acetate, glycerol, pyruvate and many TCA cycle intermediates. But no hexose, pentose or polysaccharide has clearly been shown to serve as a carbon or energy source (Bretscher and Kaiser, 1977). All the enzymes of the tricarboxylic acid cycle have been shown to be present, and the two enzymes of the pentose phosphate pathway, 6-phosphogluconate dehydrogenase and glucose 6 phosphate dehydrogenase, were also detected in $M$. santhus (Watson and Dworkin, 1968).

The levels of the TCA cycle enzymes in the extracts of $N$. scritius "vegetative cells and microcysts were seen to be the same with the exception of isocitrate dehydrogenase. This enzyme is present in microcysts at a level five times that of regetative cells (Watson and Dworkin, 1968). There is also a 
striking difference in the ability of vegetative cells and microcysts to metabolize acetate. The microcysts metabolize acetate at about $40 \%$ of the rate of regetative cells. The presence of the glyoxylate cycle could account, for

$\therefore$ these data if carbon flow were shifted away from oxidative metabolism of tbe

TCA cycle into the glyoxylate cycle (Watson and Dworkin, 1968).

The glyoxylate cycle enzymes are thought to account for the net synthesis of four-carbon dicarboxylic acids from acetate in a wide variety of microorganisms and plants (Calvin and Beevers, 1961 and Kornberg and Elsden, 1961). It is not clear why the glyoxylate cycle should be necessary in $M$. sasthess during microcyst formation, since the process is induced in the presence of casitone, which presumably provides precursors for four-carbon dicarboxylic acids. It is possible that the induction of the glyoxylate cycle reflects a shift to endogenous metabolism, perhaps. of lipid (Orlowski et al, 1972).

Hanson (1968) found that the activity of isocitrate lyase rose during the early stages of microcyst formation. Bland ef ol. (1971) showed that the vegetative cells contained low levels of both isocitrate lyase and malate synthase. These enzyme activities exhibit a rapid increase a few minutes before morphological changes begin to occur. 'Orlowski et al. (1972) concluded that the activities of the glyoxylate cycle enzymes change in a characteristic $\therefore$ manner during myxospore formation-and that the changes in activity are related to the development of the myxospore.

Dworkin and Neiderpreum (1964) have shown that $\breve{M}$. scrisiss vegetative cells and microcysts haye a functional electron transport system similar to that found in most aerobic bacteria. They have also identified the presence of $a, b$ and c type cytochromes. 
- McCurdy and Khouw (1969) carried out similar studies on another myxobacterium, Stigmatello bryssec, which belongs to the family Cystobacteraceae. S. brussec and myxococci are alike nutritionally, as they both require a large number of amino acids as sources of carbon and energy. Their growth is stimulated by the presence of polysaccharides in liquid medium even thoufh neither uses carbohydrates or their hydrolytic products.

Aithough $\alpha$-ketoglutarate dehydrogenase activity could not be demonstrated, the results of enzymatic and respiration studies indicate the presence of an operational TCA cycle with a complete terminal electron transport pathway. Cytochromes of $a, b$ and $c$ type were also detected spectrophotometrically. (McCurdy and Khouw, 1969). It has been suggested that the abserice of hexokinase in $M$. santhus might explain why it fails to.utilize carbohydrates (Dworkin, 1966). The same reasoning, however, does not hold for $S$. brunnea.

Both hexokinase and aldolase activities have been demonstrated in this organism indicating the presence of the glycolytic pathway. No explanation has been offered for the failure of $S$. brussec to use carbohydrates. Enzymes of the

- glyoxylate cycle, namely isocitrate lyase and malate synthase, were not detected in the vegetative cells of $S$. brurrec (McCurdy and Khouw, 1969).

Considerable data have been accumulated regarding the nutrition, . metabolism and morphogenesis of bacteriolytic myxobacteria but very little is known concerning the enzymes and nutrition of the cellulolytic organism $P$. cellulosum This.work is a preliminary study of the intermediary metabolism of P. celluslosum 


\section{MATERIALS AND METHODS}

\section{Orgenism and Growth Conditions}

Polycrgium cellulosum strain M209, obtained from the University of Windsor culture collection, was used for all experiments.

Working cultures were grown for $36-40$ hours at $30^{\circ} \mathrm{C}$ with shaking, in $250 \mathrm{ml}$ screw cap flasks containing $70 \mathrm{ml}$ of SP broth (Raffinose $0.1 \%$, sucrose $0.1 \%$, galactose $0.1 \%$, soluble starch $0.5 \%$, casitone $0.25 \%$, $\mathrm{M}_{B} \mathrm{SO}_{4} .7 \mathrm{H}_{2} \mathrm{O} 0.05 \%$, and $\mathrm{K}_{2} \mathrm{HPO}_{4} 0.025 \%$. McCurdy, 1963) or Staniers medium ( $\mathrm{KNO}_{3}$ $0.1 \%, \mathrm{~K}_{2} \mathrm{HPO}_{4} 0.1 \%, \mathrm{MgSO}_{4} .7 \mathrm{H}_{2} \mathrm{O} 0.02 \%, \mathrm{C}_{2} \mathrm{Cl}_{2} 0.01 \%$ and $\mathrm{FeCl}_{3} 0.002 \%$. Stanier, 1942) plus $1 \%$ cellobiose. The cells were also grown on $\mathrm{CkI}\left(\mathrm{KNO}_{3} 0.2 \%\right.$, $\mathrm{M}_{8} \mathrm{SO}_{4} .7 \mathrm{H}_{2} \mathrm{O} 0.3 \%, \mathrm{C}_{3} \mathrm{Cl}_{2} 0.14 \%, \mathrm{Fe}^{3+}$ citrate $20 \mathrm{mg}$. per litre, glucose $1 \%$, autoclared separately and $\mathrm{K}_{2} \mathrm{HPO}, 0.025 \%$, autoclayed separately. Kleinis et al., 1971) and $\mathrm{Ck} 6\left(\mathrm{MBSO}_{4} .7 \mathrm{H}_{2} \mathrm{O} 0.15 \%, \mathrm{Fe}^{3+}\right.$ citrate $0.002 \%$, autoclaved separately: $\mathrm{KNO}_{3} 0.2 \%+\mathrm{K}_{2} \mathrm{HPO}_{4} 0.025 \%$; and: glucose $0.5 \%+\mathrm{C}_{2} \mathrm{Cl}_{2} 0.15 \%$. Coucke and Voets, 1967) media. Dispersed cultures were initially established with repeated transfer of cell suspensions after omnimixing (McCurdy, 1963). These were used for nutritional and enzymological studies as well as growth rate determination, as growth could be measured turbidometerically.

\section{Chemicals}

All biochemicals were of reagent grade, unless otherwise specified.

Nicotinamide adenine dinucleotide (NAD), reduced NAD (NADH), nicotinamide adenine dinucleotidephosphate (NADP), 3-acetyl pyridine adenine dinucleotide (APAD), coenzyme A (CoA), reduced CoA (CoA-SH), S-acetyl CoA, 2,6- 
dichlorophenolindophenol (DCIP), adenosine triphosphate (ATP), thiamine pyrophosphate (TPP), phenazine methosulfate, bovine serum albumin, phenyl hydrazine hydrochloride, cis-oxaloacetic acid, $\alpha$-ketoglutaric acid, Lcysteine, DL-isocitric lactone, glutathione, 6-phosphogluconic acid, D-fructose 1,6-diphosphate, glycine, L-malate, sodium g!yoxylate and D-glucose 6-phosphate were obtained from Sigma Chemical Co. (St. Louis, Mo. U.S.A.).

Sodium fumarate and sodium arsenate were obtained from BDH Chemicals Canada Ltd. (Toronto, Canada). Potassium cyanide was obtained from Fisher Scientific Co. (Don Mills, Ontario) and succinic acid was obtained from Mann Research Laboratory Inc. (New York, New York). Preparation of Cell-free Extract

After growth for 36-40 hours, cells were harvested by centrifugation, washed twice with $0.05 \mathrm{M}$ Tris-HCl buffer, $\mathrm{pH} 7.5$, and suspended in $5 \mathrm{ml}$ of the same buffer. The cells were then disrupted by ultrasonic treatment with a Bronwill Biosonik (Bronwill Scientific, Rochester, New York) set at full power - for 2 minutes, in 20 second pulses. The cell extract was then centrifuged at $20,000 \times \&$ for 20 minutes to remove the cell debris. The supernatant was either used directly for enzyme assays or was first dialysed against $0.05 \mathrm{M}$ Tris- $\mathrm{HCl}$ buffer, $\mathrm{pH} 7.5$ for 4 hours. For assaying aconitase, succinic dehydrogenase, fumarase and malic dehydrogenase, the cell free extract was prepared in $0.05 \mathrm{M}$ phosphate buffer, $\mathrm{pH} 7.4$.

All operations were carried out at $0-4^{\circ} \mathrm{C}$. Enzyme Assays

All spectrophotometric assays were carried out at $25^{\circ} \mathrm{C}$, using $3.0 \mathrm{ml}$ quartz cuvettes ( $1 \mathrm{~cm}$ light path) in a Beckman Spectrophotometer, model DU, equipped with a Gilford automatic absorbance meter. In spectrophotometric 
methods based upon oxidation or reduction of pyridine nucleotides, 3 molar extinction coefficient of $6.22 \times 10^{6}$ at $340 \mathrm{~nm}$ was used. One unit of activity is defined as the amount of enzyme mediating the conversion of 1 umole of substrate per minute $3 t 5^{\circ} \mathrm{C}$ unless otherwise specified. Enzyme activities were recorded as specific activities. Fina! concentrations of protein in reaction mixtures were between $350-700$ us unless otherwise specified. Specific activities vere calculated accordingly. The results represent an average of at least three measurements.

The Citrate condensing enzyme (citrate-oxaloacetate lyase, COA acetylating, EC. 4.13.7) was assayed by the method of Srere and Kosicki (1961) by measuring the disappearance of acetyl-CoA at $233 \mathrm{~nm}$. The reaction mixture contained. Tris- $\mathrm{HCl}$ buffer, $\mathrm{pH}$ 8.0, 200 umoles; oxaloacetate, 1.2 umoles and acetyl COA, 0.44 umoles in a total volume of $3,0 \mathrm{ml}$. The reaction was initiated by adding $0.1 \mathrm{ml}$ of cell free extract.

Aconitase (citrate isocitrate hydrolyase, EC. 4.2.1.3) was assayed by following the increase in absorbance at $240 \mathrm{~nm}$, of cis-aconitic acid and other $\alpha, \beta$-unsaturated carboxylic acids (Anfinsen, 1955). The reaction mixture contained D,L-isocitrate, 30 umoles and phosphate buffer, $\mathrm{pH} 7.4,150$ umoles in a finsl yolume of $3.0 \mathrm{ml}$. The reaction was started by adding $0.1 \mathrm{ml}$ of the dialysed cell free extract.

Isocitrate dehydrogenase ( $L_{z}$-isocitrate:NADP oxidoreductase EC. 1.1.1.42) was assayed spectrophotometerically by measuring the reduction of NADP at 340 nm as described by Daron et al. (1966). The reaction mixture contained: TrisHCl buffer, $\mathrm{pH} 7.5,60$ umoles; $\mathrm{MnCl}_{2}, 6$ umoles; NADP, 1.5 umoles; $\mathrm{D}, \mathrm{L}-$ isocitrate, 1.5 umoles and $0.15 \mathrm{ml}$ of the cell free extract in a total volume of $3.0 \mathrm{ml}$. 
$\alpha$-ketoglutarate dehydrogenase (EC. 1.2.4.2) was assayed by the method of. Amarasingham and Davis (1965), by measuring the reduction of 3-acetyl NAD (APAD) spectrophotometerically at $365 \mathrm{~nm}$. The reaction mixture contained in 3.0 $\mathrm{ml}$ : Tris- $\mathrm{HCl}$ buffer, pH 8.5, 500 umoles, L-cysteine, 7.8 umoles, $\alpha-$ ketoglutarate , 25 umoles; CoA-SH, 0.26 umoles; APAD, 6 umoles; $\mathrm{MgCl}_{2}, 0.1$ umoles TPP, 0.1 umoles and cell free extract $0.1 \mathrm{ml}$. All components were preincubated for a period of 3 minutes, then the reaction was initiated by adding APAD and the initial increase in absorbance was used to calculate the specific activity.

Succinic dehydrogenase (Succinate:oxidoreductase, EC. 1.3.99.1) was assayed spectrophotometrically as described by Ohne et al. (1973). The reaction mixture contained potassium phosphate buffer, pH 7.4, 30 umoles, KCN, 3 umoles; succinate, 30 umoles; BSA, 21 nmoles; DCIP, 5 umoles, phenazine methosulfate, 5 umoles. The succinate dependent reduction of dichlorophenolindophenol was followed at $600 \mathrm{~nm}$. A molar extinction coefficient of $16.1 \times 10^{5} \mathrm{M}^{-1} \mathrm{~cm}^{-1}$ for DPIP was used to calculate the specific activity.

Fumarase (I-malate hydro-lyase, EC. 4.2.1.2) was assayed by the method of . Hill and Bradshaw (1969) in a reaction mixture containing phosphate buffer, $\mathrm{pH}$ $7.3,150$ umoles; L-malate, 150 umoles and $0.1 \mathrm{ml}$ cell free extract in a total volume of $3.0 \mathrm{ml}$. The increase in absorbance was measured at $250 \mathrm{~nm}$.

The presence of malate dehydrogenase (L-malate:NAD oxidoreductase, EC. 1.1.1.37) was detected by the method of Ochoa (1955) by measuring the rate of NADH oxidation at $340 \mathrm{~nm}$ in the presence of oxaloacetate. The reaction mixture contained phosphate buffer, $\mathrm{pH} 7.4,75$ umoles; oxaloacetate, 1.2 umoles; NADH, 0.3 umoles and $0.1 \mathrm{ml}$ cell extract to be assayed in a total volume of $3.0 \mathrm{ml}$. 
Fructose diphosphate aldolase (fructose-1,6-diphosphate D-glyceraldehyde3-phosphte lyase, EC. 4.12.12) was assayed as described by Christian (1953). The reaction mixture contained NAD, 0.9 umoles, fructose-1,6-diphosphate, 50 umoles, glycine, 80 umoles, sodium arsenate, 52 umoles and $0.1 \mathrm{ml}$ cell free extract in a total volume of $3.0 \mathrm{ml}$.

Hexokinase was detected by the reduction of NADP, using the method of McCurdy and Khouw (1969). The reaction mixture contained ATP, 17 umoles; NADP, 3.0 umoles; $\mathrm{MgCl}_{2}, 10$ umoles; glucose, 40 umoles; tris-acetate buffer, $\mathrm{pH} 7.4$, , 150 umoles and $0.1 \mathrm{ml}$ cell extract in a total volume of $3.0 \mathrm{ml}$. Controls containing the complete reaction mixture except NADP or ATP were also run.

- Pyruvate kinase (EC. 2.4.1.40) was determined by the coupled assay of Bucher and Pfleiderer (1955) as modified by Watson and Dworkin (1968). The reaction mixture contained Tris ( $\mathrm{pH} 7.5$ ), 150 umoles; $\mathrm{MgCl}_{2}, 10$ umoles; $\mathrm{KCl}, 100$ umoles; ADP, 1 umole; phosphoenolpyruvate, 5 umoles; NADH 0.45 umoles; lactate dehydrogenase and cell-free extract (1-2 $\mathrm{mg}$ protein) in a final volume of 3.0 $\mathrm{ml}$. The decrease in absorbance was measured at $340 \mathrm{~nm}$.

Malate synthetase (L-malate glyoxalate lyase (CoA acetylating) EC. 4.1.3.2) was assayed by the method of Dixon and Kornberg (1959), by measuring the absorption at $232 \mathrm{~nm}$ due to breakage of the thio ester bond of acetyl coenzyme $A$ in the presence of glyoxylate. The reaction mixture contained, in $3.0 \mathrm{ml}$, Tris buffer, $\mathrm{pH} 7.1,108$ umoles; $\mathrm{MBCl}_{2}, 12$ umoles; acetyl CoA, 0.15 umoles; sodium glyoxylate, 6 umoles and $0.1 \mathrm{ml}$ of cell free extract. Isocitrate lyase ( $L_{1}$-isocitrate glyoxylate-lyase EC. 4.1.3.1) was assayed by the method of Dixon and Kornberg (1959), by measuring the absorbance at 324 $\mathrm{nm}$ due to the formation of glyoxylic acid pheny! hydrazone from glyoxylate. The

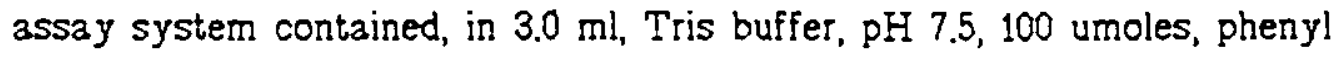


hydrazine $\mathrm{HCl}, 20$ umoles, cysteine $\mathrm{HCl}, 0.1$ umoles; $\mathrm{MgCl}_{2}, 20$ umoles and isocitrate, 2 umoles. An extinction coefficient of $1.7 \times 10^{4}$ for glyoxalate phenylhydrazone is used to calculate the specific activity.

Glucose-6-phosphate dehydrogenase (D-glucose-6-phosphate:NADP oxidoreductase EC. 1.1.1.49) activity was measured by the method of DeMoss (1955). The reaction mixture contained, in $3.0^{\prime} \mathrm{ml}$, Tris buffer, $\mathrm{pH} 7.8,150$ umoles, NADP or NAD, 0.54 umoles; $\mathrm{MBCl}_{2}, 10$ umoles, glucose-6-phosphate, 10 umoles and $0.1 \mathrm{ml}$ cell extract.

6-phophogluconate dehydrogenase (6-phospho-D-gluconate: NADP oxidoreductase (decarboxylating) EC. 1.11.44) was also assayed by the method of DeMoss (1955). The reaction mixture contained glycylglycine buffer, $\mathrm{pH} 7.5$, 600 umoles; NADP, 0.54 umoles; $\mathrm{MgCl}_{2}, 10$ umoles; 6-phosphogluconate, 5 umoles and $0.1 \mathrm{ml}$ of cell extract.

\section{Determination of Doubling Time}

Screw cap flasks with side arms, containing $100 \mathrm{ml}$ of SP broth, were inoculated with $1.0 \mathrm{ml}$ aliquots of a dispersly growing isolate of Polyangium cellulosum. Turbidometric readings were taken every 4 hours, using a KlettSummerson colorimeter.

\section{Cytochrome Absorption Maxima}

Cytochrome spectra were measured at room temperature by the method of Weston and Knowles, 1973. The cells were disrupted by sonication. Oxidized minus reduced spectra were obtained by reducing one cuvette, containing cell suspension, with $\mathrm{N}_{2} \mathrm{~S}_{2} \mathrm{O}_{4}$ and oxidizing the other cuvette by vigorous aeration.

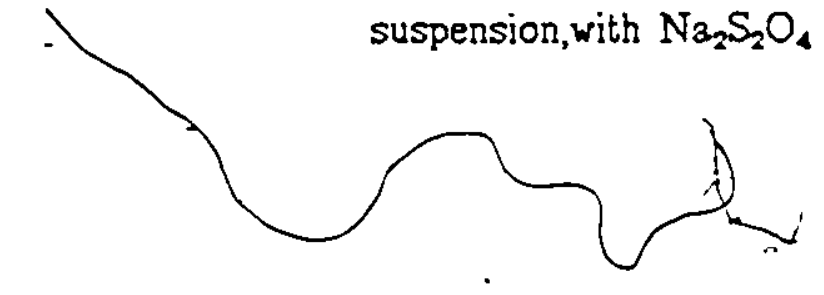




\section{RESULTS}

\section{Nutrition and Vegetztive Growth}

Polycrgium cellulosum grew quite well on both a complex medium (SP) and a chemically-defined medium (Staniers + cellobiose). This is in concurrence with earlier reports that the organism can grow on a simple salts medium containing a nitrogen source and a carbon source (Couke, 1969; Krzemieniewska and Krzemieniewski, 1937; Imschenetsky, 1959). The colonies had a bright orange pigment and seemed to etch the agar.

In liquid shake cultures, the organism grew non-dispersly either as clumps or adhering to the sides of the flask. Repeated transfers into fresh medium resulted in a dispersly growing strain. This strain was used for all subsequent studies.

Most efficient growth was observed in SP broth and Staniers medium + cellobiose. When cellobiose was substituted with glucose, it was seen that concentrations higher than $0.1 \%$ inhibited the growth of $P$. celleslosem. This was corroborated by poor growth of the organism on $\mathrm{Ck} 1$ and $\mathrm{Ck} 6$ media, both of which contain higher concentrations of glucose.

Vitamin $B_{12}$ was not essential for growth. The òrganism grew equally well in media with and without the supplement.

The doubling time of $P$. cellulosum in SP was about 22 to 24 hours.

\section{Enzymatic Activities.}

Key enzymes of the glycolytic pathway, namely hexokinase and fructose-1,6diphosphate aldolase, were found to be present in the cell-free extract of the vegetative cells (Table 1). The specific activities of these enzymes were seen 
Table 1: Glycolytic activities in crude extracts of $P$. cellulosum regetative cells.

ENZYME

$$
\begin{aligned}
& \text { SPECIFIC ACTIVITY } \\
& \text { (umoles/mg. prtn./min.) } \\
& \text { SP SP! - Glucose } \quad \begin{array}{c}
\text { Staniers medium } \\
+ \text { cellobiose }
\end{array}
\end{aligned}
$$

Hexokinase

0.0006

0.0054

0.0016

Fructose-1,6-diphosphate

0.0026

0.0267

0.0033

aldolase

Pyruvate kinase

0.0024

ND

ND

ND: not determined

* - One unit of enzyme activity is defined as that amount of enzyme which converts 1 umole of substrate per minute. Specific activity is defined as the number of enzyme units per mg. protein. 
to increase almost tenfold when the cells were grown in SP + glucose as compared to SP alone or Staniers + cellobiose. Pyruvate kinase was also detected.

Glucose-6-phosphate dehydrogenase and 6-phosphogluconate dehydrogenase activities were present in the crude extracts of regetative cells. The enzymes were active with both NAD and NADP, however, higher activities were obtained when NADP was used. Both enzymes showed higher specific activity when the cells were grown in Staniers medium + cellobiose, rather than in SP (Table 2). As shown in table 3 , the regetative cells of $P$. cellulosum were seen to possess all the enzymes of the TCA cycle. The two enzymes of the giyoxylate cycle, isocitrate lyaseand malate synthase, were also detected (Table 4).

Crude sonicated fractions of the regetative cells exhibited absorption maxima at $601,560,525,440$ and $422 \mathrm{~nm}$, as determined spectrophotometrically by difference spectra in the presence of $\mathrm{Na}_{2} \mathrm{~S}_{2} \mathrm{O}_{4}$ (Table 5).

All tables present typical results of at least thiree measurements. 
Table 2 : Pentose phosphate activities in crude extracts of yegetative cells of $P$. cellulosum

ENZYME

$\begin{array}{lc} & \begin{array}{c}\text { SPECIFIC ACTIVITY* } \\ \text { (umoles/m8. protein/minute) }\end{array} \\ \text { SP } & \text { Staniers medium + cellobiose } \\ 0.177 & 0.471 \\ 0.237 & 0.373\end{array}$

Glucose-6-phosphate

$\cdot$

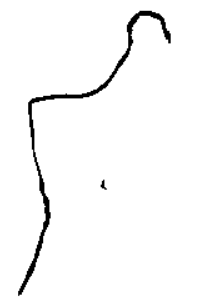

*- one unit of enzyme activity is defined as that amount of enzyme which effects a rate of change of optical density $\left(\Delta E_{940}\right)$ of 1.0 per minute during the 15-30 second interval under specified assay conditions. Specific activity is defined as the number of enzyme units per mg. protein (DeMoss, 1955). 
Table 3 : Specific activities of the TCA cycle enzymes in crude extracts. of $P$. cellulosum regetative cells.

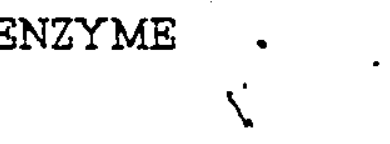

Citrate synthase

Aconitase

Isocitrate dehydrogenase

Succinic dehydrogenase

Fumarase

- Malic dehydrogenase

$\alpha$-Ketoglutarate dehydrogenase
SPECIFIC ACTIVITY'

(Enzyme units $/$ mg protein)

9.46

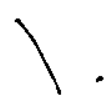

0.171

0.0034

5.12

0.028

0.0215

0.012

a : One unit of enzyme activity is defined as the-amount of enzyme which converts 1 umole of substrate per minute.

$b$ : Specific activity is defined as the number of enzyme units present per mg. protein.

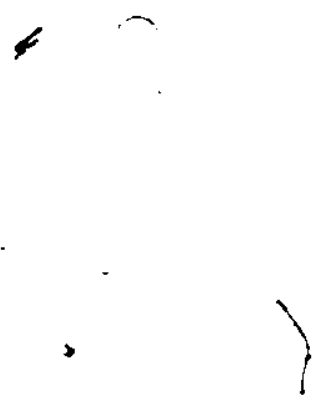


Table 4: Glyoxylate shunt in crude extracts of regetative cells of $P$. celluslosum.

ENZYME

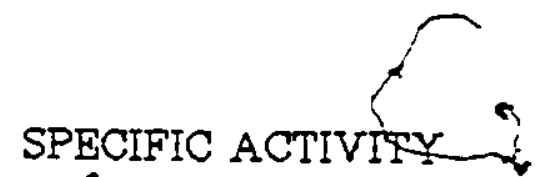

(Enzyme units/mg protein)

Isocitrate lyase

$0.179^{2}$

$\because$

Malate synthetase

$0.286^{\mathrm{b}}$

$m$

a : One unit is the amount of enzyme catalyzing the formation of 1.0 umole of glyoxylic acid phenylhydrazone in 1 minute.

$\mathrm{b}$ : One unit is the amount of enzyme catalyzing the glyoxylate dependent cleavage of 1.0 umole of acetyl-S-CoA in 1 minute.

$<$

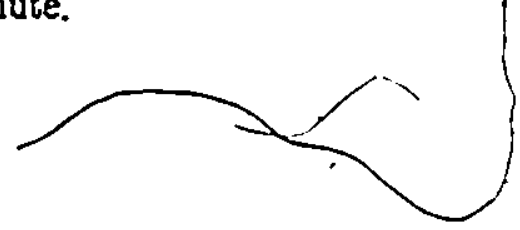

5

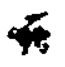


Table 5 : Position of maxima in Absorption Spectra of sonicated Polycngium -. cellulosum cells.
Absorption maxima*
Cytochrome
$-(\mathrm{nm})$
422
cyt c
440,601
cyt a
525 .
560
cyt b
cyt $b_{1}$

2

* : $\mathrm{Na}_{2} \mathrm{~S}_{2} \mathrm{O}_{4}$-reduced minus oxidised difference spectrum.

0

$\checkmark$ 


\section{DISCUSSION}

Polycngsum cellslosum is the only myxobacter known to decompose cellulose, all others are bacteriolytic. Due to this uniqué property, it plays an important role in the degradation of cellulosic materials and hence in the carbon cycle. The major respiratory and carbohydrate degradation pathways have

- been studied in Mysococcus scrithus (Watson and Dworkin, 1968) and Stigmetellc brusrea (McCurdy and Khouw, 1969). This thesis is a preliminary study of these pathways in Polycigizm cellulosum.

P. cellulogem was seen to grow on a complex medium (SP), with and without glucose, and on a chemically defined medium (Staniers medium + cellobiose) indicating that it is able to utilize carbohydrates as sole source of carbon and energy, as has been previously reported (Coucke, 1969; Peterson, 1969). Better growth was observed on medium containing cellobiose rather than glucose. Godsey (1976) showed the presence of cellulase and cellobiase activities in intact and cell free extracts of this organism. Cellulolytic bacteria, as unrelated as Rumisococcus flovefociers (Ayers, 1959), Clostridium thesmocellum (Sih et al., 1957) and Cellesibrio gsierss (Hulcher et al.,1958) apparently possess a cellulase which yields cellobiose as the sole hydrolytic product. Glucose is either not-fermented by these bacteria or there is a distinct preference for the disaccharide. It seems possible that this type of activity is widesprea among cellulolytic bacteria (Ayers, 1959). Hulcher et al (1958), suggest that enhanced growth on cellobiose may be due to the fact that the cell derives slightly more energy per mole of hexose metzbolized from cellobiose, than is obtained from glucose. 
Dworkin (1962) showed that $K$. sastisus does not metabolize low molecular weight sugars and depends on amino acids or peptides for carbon, nitrogen and energy. Similarly, Stigmetelle órunnec does not utilize carbohydrates, although growth may be stimulated by starch, glycogen or other polysaccharides for liquid cultivation (McCurdy and Khouw, 1969).

The enzymes of the tricarboxylic acid cycle were assayed and activities of citrate synthase, aconitase, isocitrate dehydrogenase, succinic dehydrogenase, fumarase, malic dehydrogenase and $\alpha$-ketog!utarate dehydrogenase were detected in $P$. celluslosum

Watson and Dworkin (1968) demonstrated the presence of a complete Krebs cycle in $N$. sorthus vegetative cells and microcysts. Dworkin.(1972) suggests that amino acids are deaminated and enter the Krebs cycle, which is linked to the gluconeogenic pathway; carbon thus proceeds upwards for polysaccharide biosynthesis in $K$. scrithus. The vegetative cells of $S$. brusnec possess most of the TCA cycle except $\alpha$-ketoglutarate dehydrogenase (McCurdy and Khouw, 1969). However, the results of the enzyme and respiration studies indicate an operational TCA cycle with a complete terminal electron transport pathway. Taking into account the growth rate of $P$. cellulosum, the levels of TCA cycle enzymes are seen to be comparable with those of $M$. zanthus (Watson et al, 1968) and $B$. subtilis (Ohne, 1973).

This study demonstrated the presence of the key enzymes of glycolysis, namely hexokinase and fructose 1,6-diphosphate aldolase, in the vegetative cells of $P$. cellulosum. The activity of these enzymes was low when the cells were grown in SP or Staniers medium + cellobiose while there was almost a tenfold increase in specific activities of both enzymes when the cells were grown in $\mathrm{SP}+$ glucose (Table 1). 
Watson and Dworkin (1968) showed that the regetative cells of $M$. scritius lack hexokinase and pyruvate kinase though all other glycolytic activities are present. Dworkin (1972) suggests that the absence of hexokinase could be of regulatory advantage to the organism and the glycolytic direction serves solely to metabolize endogenous carbohydrate. Watson et al. (1968) suggest that the principa! function of the Embden-Meyerhof pathway in this organism is gluconeogenic. This is corroborated by the absence of pyruvate kinase, which is not required for gluconeogenesis, but catalyses an irreversible flycolytic step. Pyruvate kinase activity was detected in $P$. cellulosum.

Stigmatellc brursec, does possess a hexokinase, but does not utilize carbohydrates (McCurdy and Khouw, 1969). Some other factor must therefore be responsible for the inability of this organism to use sugars. However, in Stigmatelle cureniscace, addition of glucose to casitone medium results in higher population densities and the organism has been shown to metabolize glucose slightly (Gerth and Reichenbach, 1978; Reichenbach and Dworkin, 1969). The presence of hexokinase and aldolase and the fact that the cells can frow on media containing glucose as sole source of carbon indicates the presence of a functional glycolytic pathway in $P$. celleslosem. This is further supported by the presence of pyruvate kinase.

A number of different organisms are known which metabolize glucose mainly through the Embden-Meyerhof pathway although they also possess enzymes of the hexose monophosphate pathway (Brown et ol., 1971). The pentose phosphate shunt can be used for degradation of hexoses to generate pentoses, which are required for nucleic acid synthesis, and reducing power in the form of NADPH. It can also provide energy to the cell as an alternate pathway for the oxidation of glucose. 
Glucose-6-phosphate dehydrogenase, which is the point of departure for at least two versions of hexose monophosphate pathway, was detected in the cellfree extracts of $P$. cellulosum vegetative cells. The presence of 6phosphogluconate dehydrogenase was also demonstrated. The specific activities of both enzymes were higher when the cells were grown in medium containing cellobiose rather than in SP. The activity of the enzymes with NAD in addition to NADP may be due to endogenous production of NADH in the crude extract. Both the enzyme activities have been demonstrated in $M$. scathus vegetative.

cells and microcysts (Watson and Dworkin, 1968). P. cellerlosum may use the Reptose phosphate shunt either as a biosynthetic pathway or for glucose oxidation. Further studies need to be done before any conclusions can be drawn.

The glyoxylate cycle, a modified form of the TCA cycle, is present in most plants and microorganisms. Its primary function is to enable them to utilize fatty acids or acetate as sole carbon source, and for the biosynthesis of carbohydrates from fatty acids.

The two enzymes of the glyoxylate cycle, malate synthetase and isocitrate lyase, were detected in $P$. cellulosum regetative cells. The activities of both enzymes increases during microcyst formation in $M$. zorthus (Bland et al. 1972). Induction of the glyoxylate cycle may reflect a shift to endogenous metabolism, perhaps of lipids (Orlowski et al. 1972). The glyoxylate cycle enzymes were not detected in $S$. orunsec (McCurdy and Khouw, 1969).

In conclusion, this study confirms that Polyengium cellulosum can use both sugars and amino acids as sources of carbon or energy. The key enzymes of glycolysis, pentose shunt, TCA cycle and the glyoxylate shunt are present in significant levels in the crude extracts of vegetative cells. Being a strict 
aerobe, it probably uses glycolysis in conjunction with the tricarboxylic acid cycle for carbohydrate metabolism. The role of the pentose phosphate shunt, whether catabolic or bicsynthetic cannot be determined from the preliminary results obtained in this study. 


\section{BIBLIOGRAPHY}

Amarasingham, C. R. and B. D. Davis. 1965. Regulation of $\propto$-ketoglutarate dehydrogenase in Escherichic cots. J. Biol. Chem. 240:3664-3668.

Anfinsén, C. B. 1955. Aconitase from pig heart muscle. In Methods in Enzymology. Vol. I. (S. P. Colowick and N. O. Kaplan Eds.). Academic Press, New York. p695-698.

Ayers, W. A. 1959. Phosphorolysis and synthesis of cellobiose by cell extracts from Ruminococcus flovefaciess. J. Biol. Chem. 234:2819-2822.

Bland, J., W-K Yeh, D. White and A. Hendricks. 1971. Increase in glyoxylate shunt enzymes during cellular morphogenesis in Nysococcuss zosthrss. Can. J. Microbiol. 17:209-211.

Bretscher, A. P. and D. Kaiser. 1978. Nutrition of Nysococcus sonthus, a fruiting myxobacterium. J. Bacteriol. 133:763-768.

Brown, A. T. and C. Ir. Wittenberger. 1971. Mechanism for regulating the distribution of glucose carbon between the Embden-Meyerhof and hexosemonophosphate pathways in Streptococcrs faecolis. J. Bactriol. 106:456-467

Calvin, D. T. and H. Beevers. 1961. Sucrose synthesis from acetate in the germinating castor bean: kinetics and pathway. J. Biol. Chem. 236:988-995.

Christian, W. 1953. Aldolase from yeast: In Methods in Enzymology, Vol. I.

(S. P. Colowick and N. O. Kaplan, Eds.) Academic Press, New York. p315-320.

Coucke, P. 1969. Morphology and morphogenesis of Sorastgrum compositum J. Appl. Bact. 32:24-29.

Coucke, P. and J. P. Voets. 1967. The mineral requirements of Polycrgium cellulosum. Zeitschrift fur Allgemeine Mikrobiologie 7:175-182.

Daron, H. H., W. J. Rutter and I. C. Gunsalus. 1966. Isocitrate lyase: kinetics and substrate-Tritium exchange reactions. Biochem. 5:895-899.

DeMoss, R. D. 1955. Glucose-6-phosphate and 6-phosphogluconic dehydrogenases from Leuconostoc mesenterosides. In Methods in Enzymology. Vol. I. (S. P. 
Colowick and N. O. Kaplan, Eds.) Academic Press, New York. p328-334.

Dixon, G. H. and H. L. Kornberg. 1959. Assay methods for key enzymes of the Blyoxalate cycle. Biochem. J. 72:3P.

Dworkin, M. 1962. Nutritional requirements for vegetative growth of $M y s o c o c c u s$ scrithess J. Bacteriol. 84:250-257.

Dworkin, M. and D. J. Niederpreum. 1964. Electron transport system in vegetative cells and microcysts of $M y=0 c 0 c c u s=c r i / 2 u s$. J. Bacteriol. 87:316-322.

Dworkin, M. 1966. Biology of the myxobacteria. Ann. Rev. Microbiol. 20:75-106.

Dworkin, M. 1972. The myxobacteria: new directions in studies of prokaryotic development. CRC Crit. Rev. Microbiol. 1:435-452.

Gerth, K. and H. Reichenbach. 1978. Induction of myxospore formation in Stigmatella auraritiace (Myxobacterales). I. General characterization of the system. Arch. Mikrobiol. 117:173-182.

Godsey, E. M. 1976. Physiological studies of the cellulase complex of Polyargium cellulosum M.A. Thesis. San Francisco State Univ., San Francisco. 80pp.

Hanson, C. W. 1968. Masters thesis. California State College at Los Angeles.

Hemphill, H. E. and S. A. Zahler. 1968. Nutritional induction and suppression of fruiting in Nysococcus sonthus FBa. J. Bacteriol. 95:1018-1023.

Hill, R. L. and R. A. Bradshaw. 1969. Fumarase. In Methods in Enzymology. Vol. XIII (J. W. Lowenstein, Ed.) Academic Press, New York. pp91-99.

Hulcher, F. H. and K. W. King. 1958. Metabolic basis for disaccharide preference in a Celluibrso. J. Bacteriol. 76:571-577.

Mochenetsky, A. A. 1959. Mikrobiologie der cellulose. Berlin: AkadamieVerlag. 
Kleinig, H., H. Reichenbach, H. Achenbach and J. Stadler. 1971. Carotenoid pigments of Sosorgrum cellulosem (Myxobacterales) including two new carotenoid glycoside esters and two new carotenoid rhamnosides. Archiv. fur Mikrobiologie 78:224-233.

Kornberg, H. L. and S. R. Elsden. 1961. The metabolism of 2-carbon compounds by microorganisms. Advan. Enzymol. 23:65-82.

Krzemieniewska, H. and S. Krzemieniewski. 1937. Die zellulosezersetzenden myxobakterien. Bull. Int. Acad. Pol. Sci. Lett. Serie B, 33.

Kuhlwein, H. 1950. Beitrage zur biologie und entwicklungsgeschichte der Myxobacterien. Arch. Mikrobiol. 14:678-704.

Loebeck, M. E. and H. P. Klein. 1956. Substrates for Nysococcuss virescers with special reference to eubacterial fractions. J. Gen. Microbiol. 14:281289.

6. McCurdy, H. D. 1963. A method for the isolation of myxobacteria in pure culture. Can. J. Microbiol. 9:282-285.

McCurdy, H. D. and B. T. Khouw. 1969. Studies on Strgmatella brussea. Can. J. Microbiol. 15:731-738.

MeCurdy. H. D. 1974. The Gliding Bacteria. In Bergeys Manual of Determinative Bacteriology. (R. E. Buchanan and N. E. Gibbons, Eds.) 8th Edition, The Williams and Wilkens Co. Baltimore. p76-98.

Ochoa, S. 1955. Malic dehydrogenase from pig heart. In Methods in Enzymology. Vol I. (S. P. Colowick and N. O. Kaplan, Eds.) Academic Press, New York. p685-694.

Oetker, H. 1951. Untersuchgen uber die ernahrung einiger myxobakterien. Arch. Mikrobiol. 19:206-246.

Ohne, M., B. Rutberg, and J. A. Hoch. 1973. Genetic and biochemical characterization of mutants of Bacillus subtilis defective in succinate dehydrogenase. J. Bacteriol. 115:738-745.

Orlowski, M., M. Presley, D. White and M. Chai-Wai Wong. 1972. Changes in 
activity of. glyoxylate cycle enzymes during myxospore development in Nysococcus sartisus. J. Bacteriol. 111:784-790.

Parish, J. H. 1979. Myxobacteria. In Developmental Biology of Prokaryotes. (J. H. Parish, Ed.) University of California Press, Berkeley, California. p227-253.

Peterson, J. E. 1969. Isolation, cultivation and maintenance of the myxobacteria. In Methods in Microbiology. Vol 3B. (J. R. Norris and D. W. Ribbons, Eds.) Academic Press, New York. p185-210. .

Reichenbach, H. and M. Dworkin. 1969. Studies in Stigmatella aurarticco (Myxobacterales). J. Gen. Microbiol. 58:3-14.

Reichenbach, H. and M. Dworkin. 1980. The Order Myxobacterales. In The Prokaryotes. Vol I. (M. P. Starr, H. Stolp, H. G. Truper, A. Balows and H. G. Schlegel, Eds.) Springer-Verlag, New York. p328-355.

Sih, C. J., N. H. Nelson and R. H. McBee. 1957. Biological synthesis of cellobiose. Science 126:1116-1117.

Srere, P. A. and G. W. Kosicki. 1961. The purification of citrate-condensing enzyme. J. Biol. Chem. 236:2557-2559.

Stanier, R. Y. 1942. The Cytophaga group: A contribution to the biology of myxobacteria. Bact. Rev. 6:143-196.

Watson, B. F. and M. Dworkin. 1968. Comparative intermediary metabolism of vegetative cell and microcysts of Mysococcus scrthus. J. Bacteriol. 15:253-261.

Weston, J. A. and C. J. Knowles. 1973. A soluble CO-binding c-type cytochrome from the marine bacterium Bereckec natriegens. Biochim. Biophys. Acta. 305:11-18. 


\section{VITA AUCTORIS}

Born:

Primary Education:
February 6, 1959

Rajasthan, India.

Central School, Ferozepur

India. 1964-1966.

Central School, Jullundur

Punjab, India. 1966-1967.

Central School, Pathankot

Punjab, India. 1967-1972.

Secondary Education: Kendriya Vidyalaya, Gandhinagar

Jammu, India. 1972-1975.

University Education: Department of Microbiology . Panjab University, Chandigarh India. Graduated with B.Sc.(Hons.) 1979 